\title{
Monoclonal antibodies specific to yellow-head virus (YHV) of Penaeus monodon
}

\author{
Paisarn Sithigorngul ${ }^{1, *}$, Sombat Rukpratanporn ${ }^{2}$, Siwaporn Longyant $^{1}$, Parin Chaivisuthangkura ${ }^{1}$, \\ Weerawan Sithigorngul ${ }^{1}$, Piamsak Menasveta ${ }^{2,3}$ \\ ${ }^{1}$ Department of Biology, Faculty of Science, Srinakharinwirot University, Bangkok 10110, Thailand \\ ${ }^{2}$ Marine Biotechnology Research Unit, National Center for Genetic Engineering and Biotechnology, Ministry of Science, Technology \\ and Environment, Bangkok 10400, Thailand \\ ${ }^{3}$ Department of Marine Science, Faculty of Science, Chulalongkor University, Bangkok 10330, Thailand
}

\begin{abstract}
Monoclonal antibodies specific to 22, 67 and $135 \mathrm{kDa}$ proteins of yellow-head virus (YHV) were produced from a mouse immunized with partially purified YHV isolated from the haemolymph of experimentally YHV-infected Penaeus monodon. Four groups of monoclonal antibodies were identified. One group of antibodies bound only to native protein of YHV while the others were specific to 135, 67 and $22 \mathrm{kDa}$ proteins in both native and denatured forms. All antibodies could be used to detect YHV infection by means of dot blot and immunohistochemistry. However, antibodies specific to the $22 \mathrm{kDa}$ protein gave the best immunohistochemistry results in terms of intensity and sharpness of staining.
\end{abstract}

KEY WORDS: Capsid · Dot-blot • Envelope · Immunohistochemistry · Matrix · Monoclonal antibodies · Penaeus monodon $\cdot$ Viral infection $\cdot$ YHV

Resale or republication not permitted without written consent of the publisher

Yellow-head virus (YHV) was discovered in Thailand in the early 1990s (Limsuwan 1991) and causes mortality of Penaeus monodon, the principal penaeid species commercially cultured in Thailand (Flegel et al. 1997).

Traditional methods for diagnosis of YHV infection are based on clinical signs and histopathology (Flegel et al. 1997). These methods are not highly specific and are not useful for detecting early stage infections or asymptomatic carriers. By contrast, in other studies RTPCR-based detection was highly sensitive in that it detected $0.01 \mathrm{pg}$ of purified YHV-RNA and showed evidence of infection in Penaeus monodon at 6 to $12 \mathrm{~h}$

*E-mail: paisarn@psm.swu.ac.th after experimental exposure to the virus (Wongteerasupaya et al. 1997). In situ hybridization using a cDNA fragment labeled with digoxigenin was also developed to detect YHV infection in the tissues of $P$. vannamei (Tang \& Lightner 1999). Even though these techniques are highly sensitive for virus detection, there are practical limitations for their widespread commercial application. These limitations include the need for special equipment and highly trained personnel. Consequently, assay costs are expensive for small sample numbers and this can limit PCR and in situ hybridization use.

Immunological techniques are widely used for diagnosis of many viral diseases in both human medicine and agriculture. In addition to high sensitivity and specificity, immunological methods can be simplified to obtain results quickly at relatively low cost.

The use of polyclonal antisera to detect YHV and white spot sydrome virus (WSSV) has been recently reported (Nadala et al. 1997, 1998, Loh et al. 1998). However, the assay (Western blot analysis) was not highly sensitive and could not be easily applied during field examinations. Successful tests for YHV (Sithigorngul et al. 2000) and WSSV (Poulos et al. 2001) have recently been reported. In other cases, problems with MAb specificity have been reported, i.e. with infectious hypodermal and hematopoietic necrosis virus (IHHNV; Lightner \& Redman 1998) and YHV (Kasornchandra pers. comm.). In these cases, specificity problems were related to obtaining immunoglobin M (IgM) during monoclonal antibody (MAb) production.

We reported previously a monoclonal antibody specific to YHV envelope protein (Sithigorngul et al. 2000). This was produced from a mouse immunized with crude YHV extracted from the gills of infected 
Penaeus monodon. Presumably due to the impurity of the antigen used for immunization, we obtained only a low yield of hybridomas with MAbs specific to YHV. Therefore, we describe here our attempts to obtain further MAbs specific for various YHV virion components.

Materials and methods. Viral infection and antigen preparation: Juvenile Penaeus monodon (25 to $30 \mathrm{~g}$ ) from farms near Bangkok were held in 3001 fiberglass tanks with 10 ppt seawater, ambient temperature and natural photoperiod. A YHV viral suspension prepared from the haemolymph of infected P. monodon (provided by Prof. T. Flegel, Mahidol University) was diluted (1:500) and injected (50 $\mu \mathrm{l}$ prawn $\left.^{-1}\right)$ through the arthrodial membrane of the second walking leg. When the infected prawns showed signs of feeding cessation and slow movement ( 2 to $4 \mathrm{~d}$ ), haemolymph was drawn individually from the arthrodial membrane of the fourth walking leg using a syringe fitted with a $22 \mathrm{G}$ needle. The haemolymph was diluted to double volume with modified Alsever solution (Rodriguez et al. 1995), centrifuged at $3000 \times g$ to eliminate haemocytes and stored at $-20^{\circ} \mathrm{C}$. The presence of virus in the haemolymph from individual prawns was verified by dot-blot tests using the V3-2B monoclonal antibody specific to the putative envelope protein of YHV (Sithigorngul et al. 2000) and haemolymph samples giving strong immunoreactions were pooled. To concentrate virus from the pooled haemolymph, ammonium sulfate was added to $33 \%$ saturation. The resulting precipitate was harvested by centrifugation at $3000 \times g$ for $15 \mathrm{~min}$ and the pellet was resuspended in $2 \times$ PBS $(2 \times 0.15 \mathrm{M}$ phosphate buffered saline, $\mathrm{pH} 7.2)$ (Hudson \& Hay 1976) before being subjected to further centrifugation at $100000 \times g$ for $2 \mathrm{~h}$. The pellet was redissolved in $2 \times$ PBS and the protein content was determined by Bradford's protein assay (Bradford 1976).

Heads from moribund prawns were also collected and fixed in Davidson's fixative solution for immunohistochemical studies. Haemolymph and head preparations from non-infected prawns were prepared in the same manner.

Immunization: Three Swiss mice were injected intraperitoneally with partially purified YHV (0.5 mg mouse $^{-1}$ ) mixed with complete Freund's adjuvant in a 1:1 ratio. They were subsequently injected 3 more times with the virus mixed with incomplete Freund's adjuvant at $2 \mathrm{wk}$ intervals. One week after the fourth injection, mouse antisera were collected and tested against non-infected and infected haemolymph by dot-blot assays and by immunohistochemistry using YHV-infected shrimp tissue. The best performing mouse was later boosted $3 \mathrm{~d}$ before hybridoma production.
Hybridoma production: A cell fusion procedure was adapted from the method developed by Köhler \& Milstein (1976), with modifications described by Mosmann et al. (1979). A P3X myeloma cell line was used as the fusion partner. Fusion products from 1 mouse were plated on 41 microculture plates (96 wells per plate). After identification of positive cultures by screening methods described in the next section, cells were cloned by the limiting dilution method.

Dot-blotting: Haemolymph from non-infected and infected prawns in both untreated (native) and SDSmercaptoethanol treated forms were used for screening. Haemolymph $\left(1 \mu \mathrm{l} \mathrm{spot}{ }^{-1}\right)$ samples were applied to a nitrocellulose membrane subsequently baked at $60^{\circ} \mathrm{C}$ for $10 \mathrm{~min}$ and then incubated in hybridoma conditioned media from each clone (1:20 dilution in 5\% Blotto $=5 \%$ nonfat drymilk, $0.1 \%$ Triton-X-100 in PBS) for $8 \mathrm{~h}$. After extensive washing in $0.5 \%$ Blotto, the membrane was incubated in horseradish peroxidase labelled goat anti-mouse IgG heavy and light chain specific (GAM-HRP; Biorad) antibody at 1:1000 dilution for $8 \mathrm{~h}$. The membrane was then washed for $5 \mathrm{~min}$ in Blotto and incubated in a substrate mixture containing $0.03 \%$ diaminobenzidine (DAB), $0.006 \%$ hydrogen peroxide, $0.05 \%$ cobalt chloride in PBS. Hybridoma clones that displayed immunoreactivity against infected haemolymph, but not against haemolymph from non-infected Penaeus monodon, were confirmed for viral specificity by immunohistochemistry and Western blot before cloning and cryopreservation for further investigation.

SDS-PAGE and Western blot analysis: Partially purified YHV and haemolymph from non-infected and infected prawn were separated by $12 \%$ SDS-PAGE according to the method described by Laemmli (1970). Samples were electrophoresed for $6 \mathrm{~h}$ at $30 \mathrm{~V}$ and gels were stained using Coomassie brilliant blue R-250. For Western blotting, the samples resolved by SDS-PAGE were electroblotted onto nitrocellulose membranes using a Transblot apparatus (BioRad). The nitrocellulose membrane was incubated in 5\% Blotto for $10 \mathrm{~min}$, treated with 1:200 MAb conditioned media for $4 \mathrm{~h}$ and then processed as described above in the 'Dot-blotting' section. For locating the relative position of the immunoreactive bands, the same nitrocellulose membrane was reprobed with an MAb specific to haemocyanin subunits PMVS-22 (Longyant et al. 2000) and developed in substrate without cobalt chloride.

Immunohistochemistry: Cephalothoraces from YHVinfected and non-infected live prawns were cut and fixed in Davidson's fixative solution for $24 \mathrm{~h}$ before processing for paraffin sectioning. Serial sections (8 $\mu \mathrm{m}$ thickness) were prepared and processed for indirect immunoperoxidase staining using various MAbs and GAM-HRP diluted to 1:1000 with $10 \%$ calf serum in 


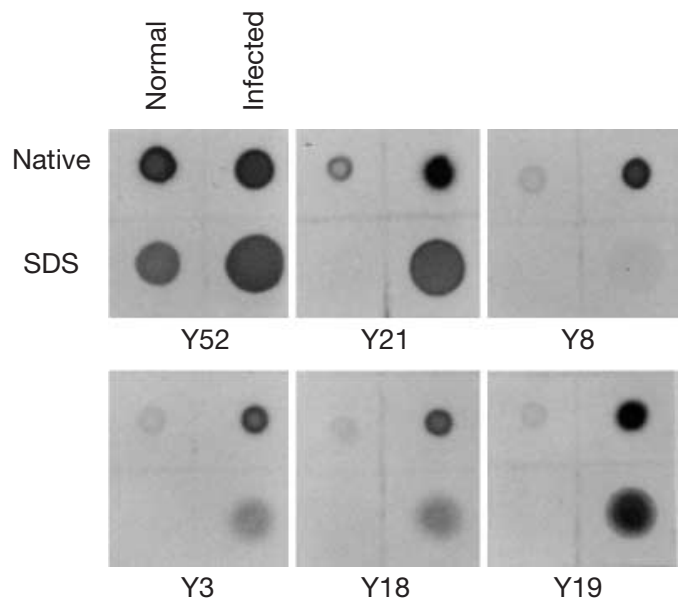

Fig. 1. Monoclonal antibody (MAb) screening by dot-blotting. Examples of $6 \mathrm{MAb}$ reactions are shown for MAb obtained in this study. MAbs Y52 and Y21 reacted with haemolymph from normal and experimentally yellow-head virus (YHV)-infected Penaeus monodon and are examples of types that were not specific to YHV. MAbs Y8, Y3, Y18 and Y19 are examples of MAbs that gave specific reactions to infected tissues and viral components only

PBS. Peroxidase activity was revealed by incubation with $0.03 \%$ DAB and $0.006 \% \mathrm{H}_{2} \mathrm{O}_{2}$ in PBS. Preparations were counter-stained with haematoxylin and eosin $\mathrm{Y}(\mathrm{H} \& \mathrm{E})$, dehydrated in a graded ethanol series, cleared in xylene and mounted in permount (Sithigorngul et al. 1999). Positive reactions were visualized as brown coloration against the pink and purple of H\&E.

Class and subclass determination: Class and subclass of mouse immunoglobulins produced by the hybridomas were determined by sandwich ELISA using Zymed's Mouse MonoAb ID Kit (HRP).

Results. One fusion trial with 41 microculture plates yielded approximately 4000 culture wells, each giving 1 to 6 colonies of hybridoma cells. The first screening by dot-blot revealed over 100 hybridoma clones that gave stronger reactions with infected haemolymph than with normal haemolymph. Some of these recognized only native preparations of YHV-infected haemolymph (Fig. 1). After screening by immunohistochemistry, supernatants from approximately 40 clones produced specific and intense staining with infected tissues. Only 21 clones were successfully established as permanent cell lines. These cloned cell lines could be divided into 4 groups according to their specificities to viral structures as determined by Western blot (Table 1, Fig. 2). The first group of MAbs recognized only native viral proteins and their precise epitope specificities were not determined. The second group of MAbs recognized the $135 \mathrm{kDa}$ protein and had similar properties to the V3-2B antibody described previously (Sithigorngul et al. 2000). The third group of MAbs constituted the major antibodies obtained in this fusion (13 clones) and recognized 67 and $140 \mathrm{kDa}$ proteins. All gave intense recognition signals with YHV-infected tissues (Fig. 3). The fourth group comprising 2 MAbs recognized a $22 \mathrm{kDa}$ protein. Both gave a more intense positive reaction with YHV-infected tissues than did the other groups MAb (Table 1, Fig 3). None of the MAbs gave positive reactions with tissues from uninfected prawns (not shown).

Most of monoclonal antibodies obtained belonged to the IgG1 subclass while MAb Y19 alone belonged to IgG2b (Table 1).

Discussion. Our trial cell fusion produced a relatively high fusion yield since almost $100 \%$ of the wells yielded 1 to 6 colonies of hybridomas. Isolation yielded relatively few YHV-positive clones, possibly due to overgrowth of the original cultures by faster growing, non-producing cells. It was surprising that most of the positive clones (13 from 21 successfully established clones and many of those that expired) were specific to the $67 \mathrm{kDa}$ protein and only a few were specific to the 135 and $22 \mathrm{kDa}$ proteins. No antibodies found were specific to the $170 \mathrm{kDa}$ viral protein described by Nadala et al. (1997). However, several antibodies (including Y21 antibody) against proteins in that molecular weight range did bind to haemolymph and tissues from uninfected prawns more weakly than to tissues of infected prawns (Fig 1). In one experiment (results not shown), mice were immunized with proteins of approximately $170 \mathrm{kDa}$ eluted from SDS-PAGE of partially purified YHV. After pre-absorbtion of the resulting antisera with normal haemolymph, no antibodies specific to infected haemolymph were found. It may be that the $170 \mathrm{kDa}$ protein described by Nadala et al. (1997) was present in too little quantity to yield a good immune

Table 1. Specificities of monoclonal antibodies tested by dot blot, Western blot and immunohistochemistry. ++++: very strong immunoreactivity; +++: strong immunoreactivity; +: detectable immunoreactivity. Underlined numbers are the representative monoclonal antibodies used in all illustrations

\begin{tabular}{|lcccc|}
\hline $\begin{array}{l}\text { Monoclonal antibodies } \\
\text { (type) }\end{array}$ & Native & Denatured & $\begin{array}{c}\text { Western } \\
\text { blot (kDa) }\end{array}$ & $\begin{array}{c}\text { Immuno- } \\
\text { histochemistry }\end{array}$ \\
\hline Y $\underline{8}, 13,22,43,45$ (IgG1) & +++ & - & - & + \\
Y $\underline{3}$ (IgG1) & +++ & +++ & 135 & +++ \\
Y1, 7, 9, 10, 11, 14, 18, 23, 24, & & & & \\
$25,26,36,38(\operatorname{IgG1})$ & +++ & +++ & 67140 & +++ \\
Y $\underline{19}$ (IgG2b), 20 (IgG1) & +++ & +++ & 22 & ++++ \\
\hline
\end{tabular}




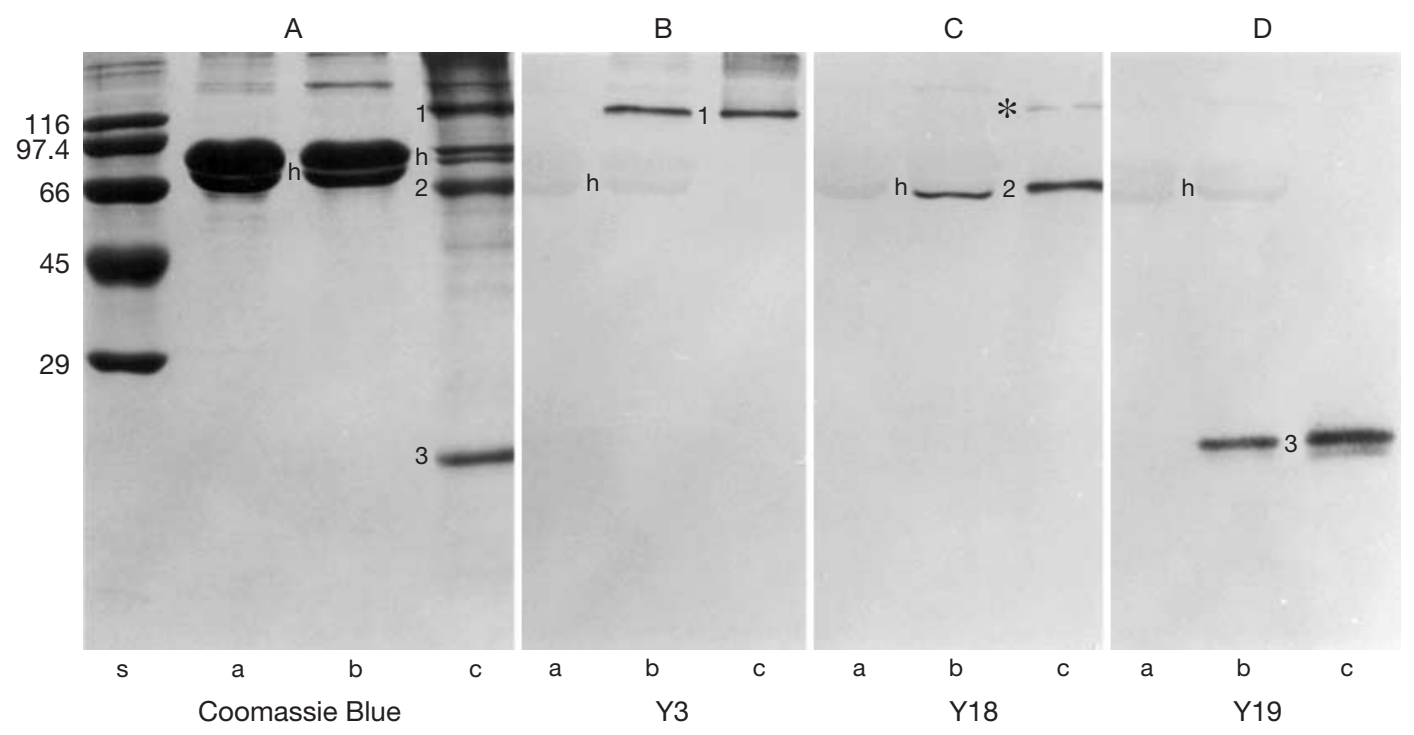

Fig. 2. SDS-PAGE and Western blot analysis of haemolymph and partially purified yellow-head virus (YHV) from Penaeus monodon. The numbers on the left-hand side indicate molecular weights of marker proteins (kDa). (A) Coomassie Blue-stained gel of proteins. Lane: $\mathrm{s}=$ molecular weight marker; $\mathrm{a}=$ crude haemolymph from an uninfected $P$. monodon; $\mathrm{b}=$ crude haemolymph from an experimentally YHV-infected P. monodon; $\mathrm{c}=$ partially purified YHV. Western blots were probed (heavy staining $=$ black in color photograph) with (B) MAb Y3; (C) Y18; (D) Y19 and subsequently reprobed with a very dilute MAb (PMVS-22) specific to

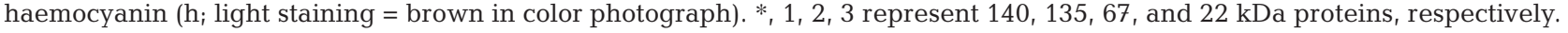
Strong positive reactions with MAb specific to different components of YHV were observed with haemolymph from YHV-infected P. monodon and with partially purified YHV, but not with haemolymph from uninfected P. monodon

response from the mouse and to obtain a specific hybridoma. In addition, Nadala et al. (1997) suggested that the $170 \mathrm{kDa}$ protein was a putative RNA transcriptase based on the assumption that YHV was a negative sense ssRNA virus similar to those in the Rhabdoviridae. However, it is now known that YHV is a positive sense ssRNA virus with no RNA transcriptase required in the virion and that it is in the Order Nidovirales (Tang \& Lightner 1999, Cowley et al. 2000).

As with our previous work (Sithigorngul et al. 2000), we suspect that MAbs specific to the $135 \mathrm{kDa}$ protein targeted the viral envelope protein, and all of these gave a single reactive band in Western blot analysis. By contrast, all monoclonal antibodies specific to the $67 \mathrm{kDa}$ protein also recognized another protein with a molecular weight of approximately $140 \mathrm{kDa}$. This result suggested that the 2 proteins might be related and that the $140 \mathrm{kDa}$ protein might be a precursor to or an aggregate of the $67 \mathrm{kDa}$ protein. Alternatively, they might be distinct proteins that share several epitopes. The $140 \mathrm{kDa}$ protein has not been reported previously, possibly due to the fact that it has close mobility to the $135 \mathrm{kDa}$ protein and is present in relatively small quantities in viral preparations when compared to other proteins. According to Nadala et al. (1997) the $67 \mathrm{kDa}$ protein is a putative capsid protein, but this may now be in some doubt since the YHV is known to be in the Nidovirales (Cowley et al. 2000). Similar questions arise as to whether the $22 \mathrm{kDa}$ protein targeted by 2 of our MAbs is really a matrix protein, as suggested by Nadala et al. (1997).

In immunohistochemical tests, the group of antibodies specific to native YHV proteins produced only weak and patchy staining reactions for tissues infected with YHV. It was possible that these antibodies recognized epitopes easily destroyed by tissue processing and that only small quantities of epitopes in areas of high viral density remained partially intact. Since the specificity of these antibodies is unknown, their use for viral identification and characterization is limited.

We expect to use the MAb reactive to both native and denatured viral proteins in comparative work with yellow-head group viruses from various geographical locations. We hope that they will provide information additional to RNA sequence information (Cowley et al. 1999, 2000) for such comparisons. If the MAb specific to with the 67 and $22 \mathrm{kDa}$ proteins actually do target more conservative capsid and matrix proteins, respectively, we might expect them to be more cross reactive and less useful in comparisons. By contrast, those antibodies targeting the envelope protein should be more selective. 

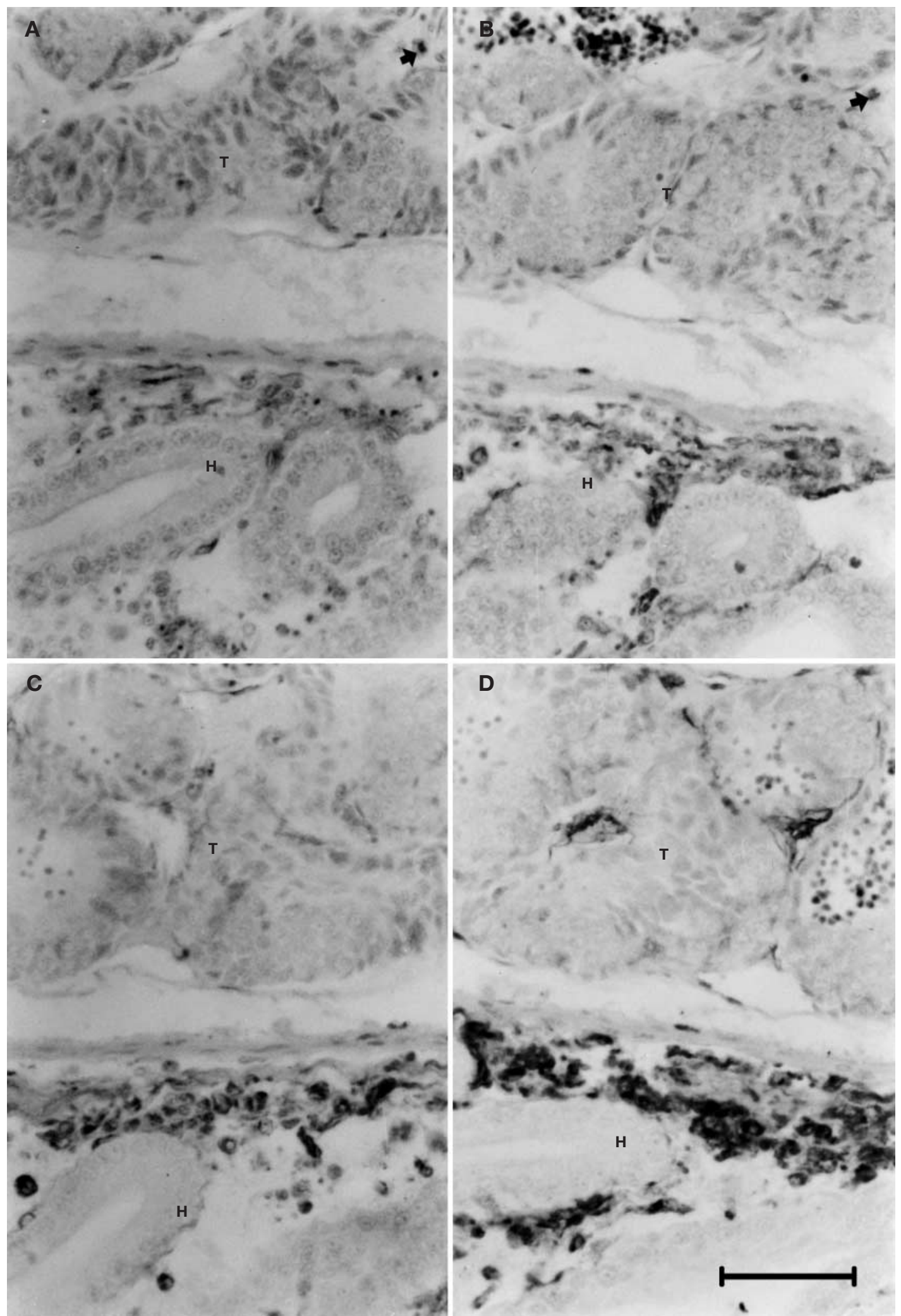

Fig. 3. Immunohistochemistry for (A) MAb Y8; (B) Y3; (C) Y18; and (D) Y19 in tissues from experimentally YHV-infected prawns. The hepatopancreas $(\mathrm{H})$ and testis $(\mathrm{T})$ showed positive immunohistochemical reactions in interstitial cells and haemocytes. 
Acknowledgements. We thank T. W. Flegel, Mahidol University, Bangkok, for kindly providing YHV stock, and valuable suggestions with the manuscript. This work was supported by the National Center for Genetic Engineering and Biotechnology, Thailand.

\section{LITERATURE CITED}

Bradford MM (1976) A rapid and sensitive method for the quantification of microgram quantities of protein utilizing the principle of protein-dye binding. Anal Biochem 72: 248-54

Cowley JA, Dimmock CM, Wongteerasupaya C, Boonsang V, Panyim S, Walker PJ (1999) Yellow head virus from Thailand and gill associated virus from Australia are closely related but distinct prawn viruses. Dis Aquat Org 36: 153-157

Cowley JA, Dimmock CM, Spann KM, Walker PJ (2000) Gill associated virus of Penaeus monodon prawns: an invertebrate virus with ORF1a and ORF1b genes related to arteriand coronaviruses. J Gen Virol 81:1473-1484

Flegel TW, Boonyaratpalin S, Withyachumnarnkul B (1997) Progress in research on yellow-head virus and white-spot virus in Thailand. In: Flegel TW, MacRae IH (eds) Diseases in aquaculture III. Asian Fisheries Society, Manila, Philippines, p 285-302

Hudson L, Hay FC (1976) Practical immunology. Blackwell Scientific Publications, London

Köhler G, Milstein C (1976) Derivative of specific antibodyproducing tissue culture and tumor cell fusion. Eur J Immunol 6:511-519

Laemmli UK (1970) Cleavage of the structure proteins during the assembly of the head of T4. Nature 227:680-685

Lightner DV, Redman RM (1998) Shrimp disease and current diagnosis methods. Aquaculture 164:201-220

Limsuwan C (1991) Handbook for cultivation of black tiger prawns. Tansatakit, Bangkok (in Thai)

Loh PC, Cesar E, Nadala B, Tapay LM, Lu Y (1998) Recent developments in immunological-based and cell culture protocols for the specific detection of shrimp viral pathogens. In: Flegel TW (ed) Advances in shrimp biotechnology. Proceedings from the Special Session on Shrimp

Editorial responsibility: Timothy Flegel,

Bangkok, Thailand
Biotechnology. 5th Asian Fisheries Forum, The National Center for Genetic Engineering and Biotechnology, Bangkok, p 255-259

Longyant S, Sithigorngul P, Thammapalerd N, Sithigorngul W, Menasveta P (2000) Characterization of vitellin and vitellogenin of giant tiger prawn Penaeus monodon using monoclonal antibodies specific to vitellin subunits. Invertebr Reprod Dev 37:211-221

Mosmann TR, Bauman R, Williamson AR (1979) Mutations affecting immunoglobulin light chain secretion by myeloma cells I. Functional analysis by cell fusion. Eur J Immunol 9:511-516

Nadala ECB Jr, Tapay LM, Loh PC (1997) Yellow-head virus: a rhabdovirus-like pathogen of penaeid shrimp. Dis Aquat Org 31:141-146

Nadala ECB Jr, Tapay LM, Loh PC (1998) Characterization of a non-occluded baculovirus-like agent pathogenic to penaeid shrimp. Dis Aquat Org 33:221-229

Poulos BT, Pantoja CR, Bradly-Dunlop C, Aquilar J, Lightner DV (2001) Development and application of monoclonal antibodies for the detection of white spot syndrome virus of penaeid shrimp. Dis Aquat Org 47:13-23

Rodriguez J, Boulo V, Mialhe E, Bachere E (1995) Characterisation of shrimp haemocytes and plasma components by monoclonal antibodies. J Cell Sci 108:1043-1050

Sithigorngul P, Panchan N, Vilaivan T, Sithigorngul W, Petsom A (1999) Immunochemical analysis and immunohistochemical localization of crustacean hyperglycemic hormone from the eyestalk of Macrobrachium rosenbergii. Comp Biochem Physiol 124B:73-80

Sithigorngul $\mathrm{P}$, Chauychuwong $\mathrm{P}$, Sithigorngul W, Longyant S, Chaivisuthangkura P, Menasveta P (2000) Development of a monoclonal antibody specific to yellow head virus (YHV) from Penaeus monodon. Dis Aquat Org 42: $27-34$

Tang KFJ, Lightner DV (1999) A yellow head virus gene probe: nucleotide sequence and application for in situ hybridization. Dis Aquat Org 35:165-73

Wongteerasupaya C, Thongchuea W, Boonsaeng V, Panyim S, Tassanakajon A, Withyachumnarnkul B, Flegel T (1997) Detection of yellow-head virus (YHV) for Penaeus monodon by RT-PCR amplification. Dis Aquat Org 31: 181-186

Submitted: May 29, 2001; Accepted: November 30, 2001 Proofs received from author(s): March 26, 2002 